\title{
A Critical Analysis of E-Government Development and Implementation in Saudi Arabia
}

\author{
Saleh Alshomrani \\ Faculty of Computing and IT \\ King Abdulaziz University \\ Jeddah, Saudi Arabia
}

\author{
Abdulrahman Altalhi \\ Faculty of Computing and IT \\ King Abdulaziz University \\ Jeddah, Saudi Arabia
}

\author{
Shahzad Qamar \\ Faculty of Computing and IT \\ King Abdulaziz University \\ Jeddah, Saudi Arabia
}

\begin{abstract}
E-government is an important tool that provides information and governmental services to citizens, businesses and employees. It also improve the efficiency, effectiveness and performance of public sector organizations. In this study, we analyzed the development and implementation of egovernment in Saudi Arabia using Chan, Lau, and Pan's (2008) E-government Implementation Framework. Initiatives taken by Saudi government have been explained using four components, i.e. ICT infrastructure, information content, egovernment info-structure and e-government promotion. The results of this study suggest that Saudi Arabia's leadership is fully committed in the developing and improving its egovernment system in order to provide best possible services to citizens and residents.
\end{abstract}

Key words

E-government, ICT, e-services

\section{INTRODUCTION}

Information and communication technology (ICT) is playing an important role in today's fast growing digital environment [1]. Looking at the importance and significance of ICT in different areas, the government around the world started thinking of using modern computing technologies to provide governmental information and services to citizens and businesses. The use of ICT in government affairs in order to provide information and deliver public services electronically to users (citizens and businesses) was termed as e-government [2]. Along with other advantages, the ultimate objective of egovernment is efficiency and effectiveness in delivering different services online [3].

E-government is a multi-disciplinary field [4]; therefore, no universally accepted definition is available. Different researchers have defined and explained its concept from different perspectives like technology, stakeholders, business models, processes, adoption and politics. Following are fewdefinitions of e-government by well-known researcher and organizations.

United Nation (2003) have explained e-government as the use of Internet and World Wide Web in order toprovide government information and services to citizens [5]. World Bank (2003) explained the concept of e-government as "refers to the use by government agencies of information technologies (such as Wide Area Networks, the Internet, and mobile computing) that have the ability to transform relations with citizens, businesses, and other arms of government" [6].
The use of latestICT in government sector give several advantages like efficient government management, less corruption, increase trans parity, revenue growth and cost reduction [6]. Layne and Lee (2001) have defined egovernment to make good use of technology by the government in delivering information and services to people, business community, government employees and other government agencies [7].

\subsection{E-government in Saudi Arabia}

Like other countries, Saudi Arabia is also giving due importance to e-government for significant benefits of national economy [8]. In 2004, Ministry of Communication and IT (MCIT) were given a task to develop a plan to provide government services electronically. MCIT started the egovernment program called "YESSER" along with the Ministry of Finance and Communication and IT Commission (CITC) with the following aims and objectives.

Table 1: Saudi e-government Aims (Adopted from YESSER, 2010) [8]

- Improve the public sector's productivity and efficiency.

- $\quad$ Provide better and convenient services for people and business.

- Increase return on investment.

- $\quad$ Provide information in a fast and accurate manner.

\subsection{United Nations E-government Surveys}

In United Nations, the Department of Economics and Social Affair (UNDESA) in 2001 initiated the e-government survey for assessing the member countries e-government program; Information and Communication Technology (ICT) for socioeconomic development [9]. So for UN has conducted six surveys in the year 2003, 2004, 2005, 2008, 2010 and 2012. In the latest survey, 193 countries have been assessed to find corresponding E-government Development Index (EGDI). EGDI is a composite measure of Online Services Index (OSI), the Telecommunication Infrastructure Index (TII) and the Human Capital Index (HCI) [10]. Mathematically its value can be derived through the following formula [10].

$\mathrm{EGDI}=0.34 * O S I+0.33 * T I I+0.33 * H C I$

In this study, Saudi Arabian e-government implementation has been analyzed with the help of UN e-government surveys and other Saudi government official reports. For this study, Chan et al (2008) e-government implementation framework [11]is adopted to describe development in Saudi Arabia. 


\section{E-GOVERNMENT IMPLEMENTATION IN SAUDI ARABIA}

In order to discuss the implementation of e-government in Saudi Arabia, the Chan, Lau \& Pan's (2008) e-government implementation framework is adopted. The said framework consist of four components, i.e. ICT Infrastructure, Information Content, E-government Info-structure and Egovernment Promotion [11]. These four components have discussed in detail in the subsequent sections.

\subsection{ICT Infrastructure}

One of the important characteristic of modern ages that changes our lives to some extent is ICT [12]. Without good ICT infrastructure, it is not possible to get maximum benefits out of e-government program. The Saudi government also realized this fact and therefore invested a lot in country's ICT infrastructure. In 2005, MCIT, Ministry of Finance; Communication, and Information Technology Commission jointly started the e-government program named "YESSER" [8]. First of all a communication network has been established by YESSER Program for e-government transactions with the aim to interconnect government agencies with the Egovernment Data Center. This communication network was name as Government Secure Network (GSN) and established according to international technical and security standards to be used as a host for the e-government National Portal and the e-government program "YESSER". GNS enabled the eGovernment Data Center to be the effective, cost saving and unifying Link for interconnecting all Government Agencies with one another with the objective of providing effective, efficient and scalable data transportation.

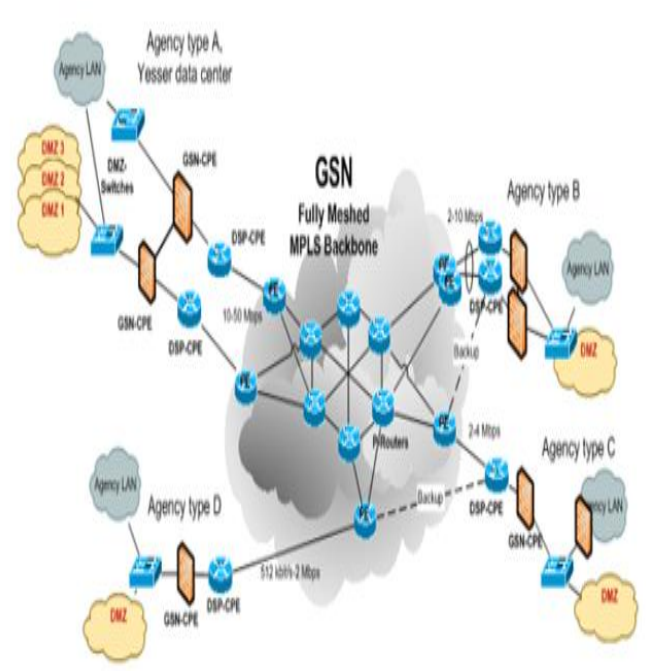

Figure 1: Government Secure Network (GNS) (Adopted from [8])
Another important element implemented and managed by YESSER Program is Government Service Bus (GSB). GSB is centralized integration platform designed to exchange the shared government data among different government agencies for e-services in an accurate, fast and secure manner.

Because of the above measures taken by the Saudi government, the UN e-government telecommunication infrastructure index (TII) has been gradually increasing. The below data has been collected from six UN e-government surveys conducted between 2003 and 2012. Telecommunication infrastructure index (TII) is important parameters in UN e-government measurement surveys. Several researchers argued the importance of telecommunication in successful development, implementation and adoption of e-government projects. The TII is calculated through the following formula.

Telecommunication infrastructure index $=$ Average (personal computer index

+ Internet user index

+ telephone line index

+ mobile subscription index

+ fixed broadband index) [18]

In this study TII1, TII2, TII3,TII4 AND TII5 is used for number of PCs, Internet Users, Fixed Telephone Lines, Mobile Subscription and Fixed Broadband Users respectively.

Table 2: Telecommunication Infrastructure Index

\begin{tabular}{|l|l|l|l|l|l|l|}
\hline Year & TII1 & TII2 & TII3 & TII4 & TII5 & TII \\
\hline $\mathbf{2 0 0 3}$ & 6.93 & 14.48 & 11.33 & 6.27 & - & 0.119 \\
\hline $\mathbf{2 0 0 4}$ & 6.46 & 14.39 & 21.72 & 13.67 & - & 0.139 \\
\hline $\mathbf{2 0 0 5}$ & 6.70 & 15.54 & 32.11 & 13.70 & - & 0.1445 \\
\hline $\mathbf{2 0 0 8}$ & 18.66 & 15.68 & 78.05 & 12.82 & 0.87 & 0.2110 \\
\hline $\mathbf{2 0 1 0}$ & 30.55 & 16.27 & 142.85 & 68.25 & 4.16 & 0.4031 \\
\hline $\mathbf{2 0 1 2}$ & 41.00 & 15.18 & 187.86 & - & 5.45 & 0.4323 \\
\hline
\end{tabular}

UN Telecommunication Infrastructure Index

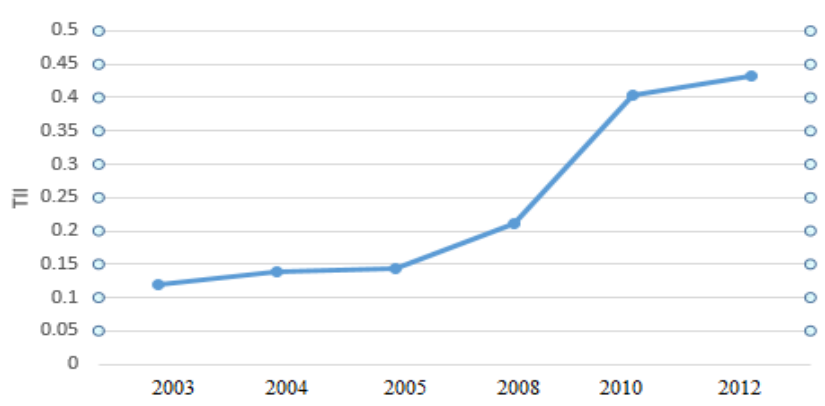

Figure 2: Saudi Arabia TII (2003 - 2012)

The above table and figure 2 clearly illustrates the improvement in Saudi Arabia over all Telecommunication Infrastructure Index and individual indexes year by year. In 2003, Saudi Arabia's overall telecommunication infrastructure (TII) value was 0.119 that now reached to 0.4323 in 2012 . Internet user per 100 personshave been continuously increasing between 2003 and 2012. In 2003, the number of internet users per 100 persons were only 6.93 but this figure increased to 41.00 per 100 persons in 2012. Another important index is 'Mobile Subscriber' whose index value has 
also increased with a rapid speed. In 2003, mobile subscriber's number per 100 persons was 11.33 but in 2012, the index value dramatically reached to 187.86 . Similarly, a continuous increase has also been noted in 'Broadband Users' per 100 persons, which reached from 0.87 (in 2008) to 5.45 (in 2012).

\subsection{Information Content}

In developing e-government system, the Saudi Arabia hasadopted a UN "Five Stage e-government Model". The five stages are:

Table: 3: The stages of e-government

\begin{tabular}{|l|l|}
\hline Stage & Description \\
\hline Emerging & $\begin{array}{l}\text { An official government online } \\
\text { presence is established. }\end{array}$ \\
\hline Enhanced & $\begin{array}{l}\text { Government sites increase, } \\
\text { information becomes more } \\
\text { dynamic. }\end{array}$ \\
\hline Interactive & $\begin{array}{l}\text { Users can download forms, email } \\
\text { officials and interact through web. }\end{array}$ \\
\hline Transactional & $\begin{array}{l}\text { Users can actually pay for services } \\
\text { and other transactions online. }\end{array}$ \\
\hline Seamless & $\begin{array}{l}\text { Full integration of e-services } \\
\text { across administrative boundaries. }\end{array}$ \\
\hline
\end{tabular}

In 2001, when Saudi web portal was initially launched, it was in "Emerging Stage" with few online services. Today Saudi'se-government web portal is providing up totwo thousand services for its citizens, businesses and other government agencies. According to [13], twelve Saudi ministries websites are currently at stage IV i.e. transactional and only one ministry i.e. Ministry of Higher Education is at stage V (seamless).

Online Services in another important indicator group used by $\mathrm{UN}$ in its e-government surveys. To find the index value of service index, each country national, e-services and eparticipation portals along with web sites of five important ministries i.e. education, labor social services, health, finance and environment are assessed [10]. There are four sub-indexes in this group i.e. Emerging (OS1), enhanced (OS2), transactional (OS3) and connected approach (OS4). The following table represent the Saudi Arabia online services index value from 2010 and 2012.

Table 4: Saudi Arabia Online Service Indexes

\begin{tabular}{|l|l|l|l|l|}
\hline Year & OS1 (\%) & OS2 (\%) & OS3 (\%) & OS4 (\%) \\
\hline $\mathbf{2 0 1 0}$ & 46 & 25 & 22 & 5 \\
\hline 2012 & 92 & 60 & 77 & 67 \\
\hline
\end{tabular}

The above table shows continuous improvement in online services provided by the Saudi government to its citizens, business and government agencies. According to UN egovernment survey 2012, 92\% Saudi public sector organization have online presence. The connected approach (OS4) has remarkably increased from 5\% in 2010 to $67 \%$ in 2012, which is a great achievement of Saudi Arabia egovernment. This improvement shows that Saudi leadership is committed in providing online services through modern information and communication technology.

\subsection{E-government Infostructure}

E-government infostructure is the combination of information contents and ICT infrastructure in order to get maximum benefits out of the e-government project. Saudi's national portal (www.saudi.gov.sa) is positioned as the e-government info-structure through which citizens, residents, businesses, visitors and other government agencies can access online services in effective and efficient way. The Saudi portal make it possible to provide e-services anytime from anywhere through modern ICT. Saudi Arabia's YESSER Program has implemented and managed Government Service Bus (GSB), which is an entity, containing intermediary systems of hardware and software designed to activate the exchange of shared government data among different government agencies and to deliver e-services in effective manner [].

The Saudi official portal providing a wide range of e-services efficiently and effectively. The portal provides 2000 services that are organized in to three sections i.e. citizens and residents; businesses; and visitors. Links to various government organizations, ministries, e-payment, general information about YESSER Program, news, Saudi stock exchange are available on home page [14]

E-Dashboard portal is a good addition in the Saudi e-services, which have the ability to verify the identity of the citizen registered with Ministry of Interior and then serves as a singleportal, which make able to access all online facilities. Another important initiative by the Saudi government is Open Government Data, which give citizens a right to access different ministries and agencies documents and reports in order to encourage electronic participation with the aim to obtain public opinion [10].

\subsection{E-government Promotion}

It is not enough for governments to develop and implement egovernment system but it needs to be adopted and properly used by the citizens and businesses in a country[15]. Therefore, a good e-government promotion strategy is required for adoption of e-government. In their framework, Chan et al., (2008) explained three-prong approach of awareness, assistance and assurance for e-government promotion.

Awareness mean the adoption of different activities and strategies for raising the level of knowledge about e-services in Saudi citizens and residents. For this purpose, YESSER Program has 'Media and Public Relations' department whose responsibility is marketing services, promotion and public relations in order to increase the awareness about Saudi egovernment program. The media affair department is also following up YESSER Program related press news published in print and electronic media, preparing informative articles, communication with advertisement agencies to promote egovernment. It also managing events relating to YESSER Program, in case new e-service was launched, promotional efforts through some form of media release is made and also to invite senior government official for inauguration ceremony of new e-services etc. 
Increasing the level of awareness about e-government is not enough; the second prong is assistance that means to provide facilities to users of the e-government system who may find it difficult to use the e-services. In this regard, the important task is to improve the literacy rate especially computer literacy rates. An important indicators group is Human Capital Index (HCI) that consists of two parameters i.e. adult literacy (HCI1) and gross enrollment ratio (HCI2) and calculated through the following formula.

Human capital index $=2 / 3 \times$ adult literacy index $+1 / 3 \times$ gross enrollment index [18]

Table 5: Human Capital Indexes

\begin{tabular}{|l|l|l|l|}
\hline Year & HCI1 & HCI2 & HCI \\
\hline $\mathbf{2 0 0 3}$ & - & - & $\mathbf{0 . 7 1 0}$ \\
\hline $\mathbf{2 0 0 4}$ & - & - & 0.710 \\
\hline $\mathbf{2 0 0 5}$ & - & - & 0.710 \\
\hline $\mathbf{2 0 0 8}$ & 82.9 & 75.9 & 0.8056 \\
\hline $\mathbf{2 0 1 0}$ & 85.0 & 80.39 & 0.8346 \\
\hline $\mathbf{2 0 1 2}$ & 86.13 & 81.55 & 0.7677 \\
\hline
\end{tabular}

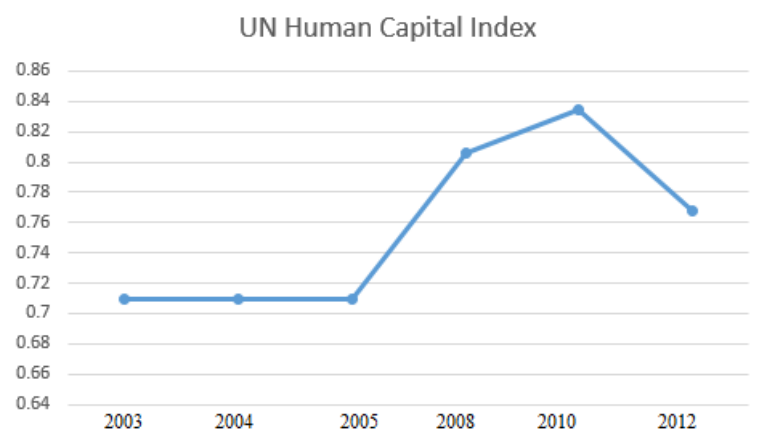

Figure 3: UN Human Capital Index

The above table shows that Saudi's Human Capital Index (HCI) is improving year by year. The HCI value notably increased from 0.710 to 0.7677 between 2003 and 2012. The adult literacy rate is improved from 82.9 in 2008 to 86.13 in 2012 and gross enrollment ratio is gone up to 81.55 in 2012 , which was 75.9 in 2008.

The last prong is assurance in three-prong e-government promotional strategy. Citizens and businesses are always concern about the privacy and security of personal data[17]. Therefore, assurance strategy is required in order to assure that all personal information and transaction would be safe and there is no need to worry about personal data leakage. Advanced information and communication technologies made it possible to secure online transactions in Saudi Arabia. The infrastructure department in YESSER Program is responsible for supervising over infrastructure of the e-government in addition to its development and operation. The main task of infrastructure department is to "specify and apply information security standards and procedures required to manage all components of Infrastructure in accordance with international high level standards followed in this regard" [8].

\section{CONCLUSION}

The importance of e-government cannot be ignored in today's modern ICT world. Along with developed nations, developing and least developed nations are also giving due importance to electronic form of government. In this study, we have discussed Saudi Arabia's e-government development and implementation through Chan, Lau and Pan (2008) Egovernment Implementation Framework. The research identified that Saudi Arabia's e-government system is performing good in all four components i.e. ICT Infrastructure, Information Content, E-government Infostructure and E-government Promotion of the framework. This fact is also clear from United Nations e-government surveys conducted between 2003 and 2012. The continuous growth in Saudi's e-government showed the commitment and interest of top the leadership of the country in electronic form of government (e-government).

\section{REFERENCES}

[1] Ndou, Valentine. "E-Government for Developing Countries: Opportunities and Challenges." The Electronic Journal of Information Systems in Developing Countries 18, no. 0 (July 1, 2004). https://www.ejisdc.org/ojs2./index.php/ejisdc/article/vie w/110.

[2] Saleh Alshomrani and Shahzad Qamar. Hybrid SWOTAHP Analysis of Saudi Arabia E-Government. International Journal of Computer Applications 48(2):17, 2012. Published by Foundation of Computer Science, New York, USA.

[3] Fang, Zhiyuan. "E-Government in Digital Era: Concept, Practice, and Development." International Journal of the Computer, the Internet and Management 10, no. 2 (2002): 1-22.

[4] Peng, Li, and Wang Xukun. "China's E-Government Research and the Conception of Its Disciplinization." 2398-2402. IEEE, 2010. doi:10.1109/ICEE.2010.606.

[5] United Nations Department of Economic and Social Affairs. 2003. UN e-government survey 2003. [online], Available http://unpan1.un.org/intradoc/groups/public/documents/u n/unpan016066.pdf [Accessed 20/11/2013]

[6] World Bank. 2003. E-government Definition [online.] Available at http://web.worldbank.org/WBSITE/EXTERNAL/TOPIC S/EXTINFORMATIONANDCOMMUNICATIONAND TECHNOLOGIES/EXTEGOVERNMENT/0,,contentM DK:20507153 menuPK:702592 pagePK:148956 piPK: 216618 theSitePK:702586,00.html [Accessed 20/11/2013]

[7] Layne, Karen, and Jungwoo Lee. "Developing Fully Functional E-Government: A Four Stage Model." Government Information Quarterly 18, no. 2 (2001): 122-136.

8] YESSER Program, (2013). E-government Project: Web site of Saudi Arabia e-government., http://www.yesser.gov.sa/en/Pages/default.aspx, [Accessed 22/11/2013] 
[9] United Nations Department of Economic and Social Affairs. 2004. GLOBAL E-GOVERNMENT READINESS REPORT 2004: TOWARDS ACCESS FOR OPPORTUNITY. [Online], Available at http://unpan1.un.org/intradoc/groups/public/documents/u n/unpan019207.pdf [Accessed 30/11/2013]

[10] United Nations Department of Economic and Social Affairs. 2012. E-Government Survey 2012: EGovernment for the People. [Online], Available at http://unpan1.un.org/intradoc/groups/public/documents/u n/unpan019207.pdf [Accessed 30/11/2013]

[11] Chan, Calvin, YiMeng Lau, and Shan Pan. "EGovernment Implementation: A Macro Analysis of Singapore's E-Government Initiatives." Government Information Quarterly 25, no. 2 (2008): 239-255.

[12] Drew, Mohammed Alshehri; Steve J. "E-Government Principles: Implementation, Advantages and Challenges.” International Journal of Electronic Business 9, no. 3 (2011): 255-270.

[13] Alfarraj, Osama, Steve Drew, and Rayed AlGhamdi. "EGovernment Stage Model: Evaluating the Rate of Web Development Progress of Government Websites in Saudi Arabia." arXiv Preprint arXiv:1211.2406 (2012). http://arxiv.org/abs/1211.2406.

[15] Saudi e-government Portal. www.saudi.gov.sa.

[16] Bwalya, Kelvin Joseph. "Factors Affecting Adoption of E-Government in Zambia." The Electronic Journal of Information Systems in Developing Countries 38 (2009). http://www.ejisdc.org/Ojs2/index.php/ejisdc/article/view/ 573.

[17] Zhu, Weiheng, and Shun Long. "Privacy Preservation in E-Government." 4264-4267. IEEE, 2010. doi:10.1109/ICEE.2010.1071.

[18] United Nations (2010). UN EGovernment Survey 2010, [Online], [Retrieved Feb 10 ${ }^{\text {th }}$ 2014], http://unpan1.un.org/intradoc/groups/public/documents/u n/unpan038851.pdf

\section{AUTHOR'S PROFILE}

Dr. Saleh Alshomrani is an Associate Professor of Information Systems Department at King Abdulaziz University. $\mathrm{He}$ is also serving now as the Vice-Dean of Faculty of Computing and Information Technology,- North Jeddah Campus at King Abdulaziz University. He earned his Bachelor degree in Computer Science (BSc) from King Abdulaziz University, Saudi Arabia 1997. He received his Master degree in Computer Science from Ohio University, USA 2001. He Also earned his Ph.D. in Computer Science from Kent State University 2008, Ohio, USA, in the field of Internet and Web-based Distributed Systems and Technologies. His research areas include: Web Data Mining, E-Learning, E-Government, and he is actively working in this area.

Dr. Abdulrahman Altalhi is an associate professor of Information Technology at the College of Computing and Information Technology at King Abdulaziz University. He has obtained his Ph.D. in Engineering and Applied Sciences (Computer Science) from the University of New Orleans on May of 2004. He served as the chairman of the IT department for two years (2007-2008), the Vice Dean of the College for five years (2008-2014). Currently, he is serving as the dean of the college of Computing and Information Technology. His research interest include: Wireless Networks, Software Engineering, and Computing Education.

Mr. Shahzad Qamar is working as a Lecturer in Department of Information Systems at King Abdulaziz University North Jeddah Branch, Saudi Arabia. Shahzad Qamar has done MSc Wireless and Mobile Networks from Bournemouth University UK in 2009. His research focus is on new emerging technologies like e-government, m-government, ICT4D, Green Computing and Cloud Computing. 